\title{
Solving Religious-Based Social Conflict between the Sunni and the Shia in Sampang, Madura: When Can the State Stop Being Responsible?
}

\author{
Marcella Elwina Simandjuntak, Valentinus Suroto, B. Danang Setianto and Yohanes Budi Sarwo \\ Departmentof Law, Facultyof Law and Communication \\ Soegijapranata Catholic University, Semarang, Central Java, Indonesia \\ Email: marcella@unika.ac.id, suroto@unika.ac.id, benny@unika.ac.id, budisarwo@unika.ac.id
}

\begin{abstract}
The legal basis for resolving social conflicts in Indonesia is Law No. 7 Year 2012 and Government Regulation No. 2 Year 2015 on the Handling of Social Conflict. Both of these rules govern the state's responsibility when social conflict occurs in the framework of the protection of human rights. One type of social conflict that the state must solve is religious-based social conflict. The issue arises when the state has made a serious effort to do its obligations, but, on the other hand, the warring parties are unwilling to cooperate and even reluctant to pursue peace. This reluctance certainly puts the country in an awkward position. This paper will address the difficulties that arise in resolving religious-based Sunni-Shia conflicts that occur in Sampang, Madura, since post-conflict peace efforts have been made by the state for more than 5 (five) years. To date, one of the warring parties, the Shia group, still lives in a shelter outside the conflict area and, in the name of human rights, they insist on returning to their hometown. On the other hand, the Sunni are only willing to accept the Shia back to their hometown provided they have to return to the Sunni religious teachings because of the belief that Shia teachings are heresy. Under the existing conditions, the important question to be answered is how long does the state have to be responsible for resolving the conflict? If the state is not responsible, it will be criticized for violating human rights, but, on the other hand, the two conflicting parties remain unmoved and insist on their demandandtruth.
\end{abstract}

Keywords: state responsibility, social conflict, Sunni-Shia religious conflict

\section{Introduction}

Indonesia is an archipelagic country extending 5,120 kilometers from east to west and 1,760 kilometers from north to south. It has approximately 13,466 islands, extends from Sabang to Merauke with an area of about $5,193,250 \mathrm{~km} 2$. Islands in Indonesia are very fertile and endowed with a wealth of natural resources, arts, cultures, and customs. With a population of over 258 million by 2016, Indonesia is the fourth most populous country in the world and has the largest Muslim people in the world with approximately 207 million people. The rest population is Protestant, Catholic, Hindu, Buddhist, Confucian, and those who embrace Indonesian indigenous religions or indigenous worship.

With the diversity of ethnic groups, cultures, customs, and religions, Indonesia is a country with a very high potential for conflict. Given such variety, since the time of independence, consciously, the founding fathers chose the motto of Bhinneka Tunggal Ika, which means different but still one or unity in diversity. But in reality, even this slogan cannot prevent various conflicts based on religion or ethnicity from taking place in Indonesia. Ichlasul Amal even suggests that Indonesia's modern history is a history of conflict [1], because Indonesian history proves that even small issues can trigger multidimensional and prolonged social disputes. Regarding the conflict in Indonesia, Hadar states that "... Many social conflicts in Indonesia are multidimensional. Let alone; once the conflict erupts, other parties will try to take advantage of it so that it will prolong the conflicts [2]." In 
line with Hadar's statement, despite the dimension of religion (or ethnicity), it can be said that conflicts in Indonesia most likely involve parties that try to gain economic or political benefit.

Although guaranteed in the Constitution, in Law no. 39 of 1999 on Human Rights and Law no. 12 of 2005 on Ratification of International Covenant on Civil and Political Rights, religious discrimination against specific groups is still common in Indonesia. This is done either by the state or by particular groups by reducing, hindering, limiting, or even uprooting a person's or the collective right to embrace a religion or belief and worship according to their religion and belief. One form of discrimination that appears is against the establishment of worship houses of a particular religion in one area and the prohibition to worship for its adherents. At some point, the pressure and frustration of the people being discriminated against may lead to open conflicts. Apparently, everywhere, discrimination causes conflicts. One such conflict is the conflict between the Sunni and Shia communities in Sampang, Madura. Until this paper was written, the Sunni-Shia conflict that occurred in Sampang still leaves various problems. Peace efforts have been implemented by the Government for more than 5 (five) years, but many issues are still unresolved. If the conflict persists, how long and to what extent should the state continue to bear the burden or be responsible for resolving the conflict? If the state does not do anything, it will be criticized for abusing and violating human rights. On the other hand, if the two conflicting parties remain unmoved and insist on believing that their own belief is the only truth, then should the state be responsible whatsoever for the conflicts? How long and to what extent should the state continue to bear the burden for resolving the conflicts?

\section{Factors Causing Violence and Conflict between Religions (and Ethnic Groups)}

Conflict is a symptom inherent in society, nor can it be eliminated from community because it is dialectical and inherent or all-present in society. According to Ralf Dahrendorf, what the state can do is simply to make the conflict not erupt into violent activities. Dahrendorf's study is based on the fact that each association tends to have two dichotomous classes: the class that has power and/or authority (the authority) and the other one that has no power and/or authority (the subordinate). Furthermore, Dahrendorf states that the conflicts that occur in society are primarily due to unequal distribution of power, and the class with the power has interests opposed to the one that does not. Authorized groups will always strive to maintain the status quo so that they can continue to dominate those who have no authority. Under these conditions, potential conflicts arise so that, if not properly managed, they will become open violent conflicts [3].

Ironically, a Jewish rabbi named Jonathan Sacks, quoting Blaise Pascal, states that 'Men never do evil so completely and cheerfully as when they do it from religious conviction'. Furthermore, in his book entitled 'Not in God's Name: Confronting Religious Violence' which became a bestseller, he states that: ... too often in the history of religion, people have killed in the name of God of life, wage war in the name of the God of peace, hated in the name of the God of love and practised cruelty in the name of the God of compassion. When this happens, God speaks, sometimes in a still, small voice almost inaudible beneath the clamour of those claiming tospeak on his behalf. What he says at such times is: Not in My Name... [4].

Regarding the causes of the conflict, Bojana Blagojevic mentioned that [5]: "... Conflict occurs when a certain structure of conditions and conditions converge: a major structural crisis; the presence of historical memories of inter-ethnic-religious grievances; institutional factors that promote ethnic-religious intolerance; manipulation of historical memories by political entrepreneurs to evoke emotions such as fear, resentment, and hate toward the "other". Each conflict has its own unique characteristics and in different contexts, some of which are more prominent than the others. All of them are the "common denominators" necessary for a conflict to occur ..."

In a chapter entitled "Why Are We so Groupish?" in his book The Righteous Mind: Good People are Divided by Politics and Religion, Jonathan Haidt states that 'morality binds and blinds' [6]. In addition to bringing together a group of people who have the same opinion, morality is also blinding. It can dehumanize mankind. Morality forms a group of people that is difficult to be united with other groups that have different morality perspective and religious views. Such blindness has the potential to generate conflict and violence. Generally, a source of 'pure' religious conflict occurs because of the absolute claim of truth by a religion. To fight for the righteousness of a religion, often 'violence' is justified when it is needed. When conflict is motivated by a 'religious proposition', it will have enormous power or impetus to deny a space for disagreement or 'dialogue' and violence is justified. Actually, a type of 'purely' based religious conflict is rare. They are 
generally motivated by other interests that are not related to religious teachings or beliefs, but religion is then used as a tool of legitimacy to justify and legalize conflicts.

\section{Sunni and ShiaConflict in Sampang, Madura}

Not only in Sampang, Madura, for a long time and in various parts of Indonesia, Shia community activities have gained strong resistance from the surrounding community. In some areas, this resistance does not develop into an open conflict as happened in Sampang. Until the time this research was conducted, the Sunni-Shia conflict that occurred in Sampang still leaves various problems. Although it started to happen more than 5 (five) years ago, the Government still cannot solve this problem. In reality, until now the Shia Community still lives in a shelter provided by the Government in Puspa Agro Flats in Sidoarjo, East Java, which is a little bit far away from their hometown. They have not been able to return to their hometown in Karang Gayam Village, Omben Sub district, Sampang, Madura due to the refusal by the local community whose members are the Sunni. Apart from movements that actively reject the existence of the Shia communities' elsewhere in Indonesia, we have information from various sources that the conflicts in Sampang are primarily due to gaining religious authorities and pilgrims among religious leaders. The difference in faith and belief does not in itself breed the conflict. The conflict in Sampang occurred because there are two parties who fight over limited resources, i.e. pilgrims. It is understandable that when a new developing group comes up with different values, another established group will consider it as a threat.

One of the reasons why the Sunni community does not accept the Shia community is mainly related to the teachings of Shia community leaders who are considered to deviate from the teachings of Islam, and those disturb the public. Regarding this matter, the leader of the Shia in Sampang namely Ustad Tajul Muluk argues that it is not true that their teachings are deviant. Hostility and hatred are intensively disseminated against them. Also, he argues that there is an ongoing effort unilaterally to establish Shia as a heresy. In reality, the accusation that Shia is a heresy has indeed led to a court decision imposing a prison sentence against Ustad Tajul Muluk who is considered to conduct a religious blasphemy as regulated in Article 156a of the Indonesian Penal Code (KUHP). Another reason expressed by the Sunni community as to why the conflict occurred is because they think the leader of the Shia community, Ustad Tajul Muluk, has denied an agreement to stop its teaching activities (da'wah) that are considered 'heretical'.

If the Sunni community thinks that Shia teachings are deviant, then the Shia community, represented by Ustad Tajul Muluk, argues that there is a unilateral coercion or judgment on their teachings and activities by the Sunni. He insists that his da'wah is pure to strengthen the internal of his own Shia pilgrims, and as a constitutional state, the constitution and legislation should protect every citizen to worship and observe worship according to his personal belief or faith.

The Sunni-Shia open conflicts itself began when the Shia community was about to commemorate and celebrate the Maulid Nabi (Prophet Mohammed birthday) event around April 2011. The Sunni community blocked the access to the location of the celebration and barred the Shia community from attending the event. The peak of the Sunni-Shia conflict in Sampang took place in August 2012 resulting in casualties, injuries (including police forces) and property damage with the burning down of homes and property of the Shia community. For security reasons, by the Government, the Shia community was evacuated to the Sports Center (GOR) in Sampang as a temporary shelter. Furthermore, for the same reason, the East Java Provincial Government eventually transferred all Shia refugees to Rental Puspa Agro - a sheltered compound, where they remain staying there until today. After for almost five years after the incident, there are still 82 families with a total of 335 people of Shia community living in refugee camps. This number is constantly changing because in refugee camps some refugees are married and have sons and daughters who eventually also earn the refugee status.

\section{The Role of the Government in Handling Sunni-Shia Conflicts}

It has been mentioned that the legal basis for settling social conflicts in Indonesia is Law no. 7 of 2012 on the Handling of Social Conflict and its implementing regulation is the Government Regulation no. 2 Year 2015 on the Handling of Social Conflict. Both of these rules govern the state's responsibility when social conflict occurs in the framework of the protection of human rights. The followings are some of the definitions contained in Article 1 of Law no. 7 Year 2012 on Handling Social Conflict. In this law, it is explained that Conflict is a 
conflict and/or physical clash with violence between two or more community groups that take place within a certain time and has a wide impact resulting in insecurity and social disintegration. Thus, it disrupts national stability and hampers national development. Furthermore, this law also mentions that Conflict Handling is a series of systematic and planned activities in situations and events before, during and after a conflict that includes conflict prevention, cessation of conflicts and post-conflict recovery.

Based on this understanding, there are 3 (three) responsibilities of the state in handling conflicts, i.e. 1) to prevent conflicts, 2) to terminate conflicts, and 3) to restore the post-conflict situation. Definition of Conflict Prevention in the law is a series of activities undertaken to prevent the occurrence of Conflict with the increase of institutional capacity and early warning system. The definition of Conflict Termination is a series of activities to end violence, rescue victims, limit extensions and escalation of the conflict, and prevent the increasing number of victims and loss of property; and the notion of Post-Conflict Recovery is a series of activities to restore circumstances and improve harmonious relationships in the community after the conflict through reconciliation, rehabilitation and reconstruction activities.

From the beginning of the conflicts to the present, the Government has done to do its responsibility for dealing with the conflicts between these Sunni and Shia communities. When an open conflict occurred, for example, the Government played an active role in rescuing the victims, limiting the extension and escalation of the conflict, and evacuating one of the conflicting parties, i.e. the Shia community to prevent the increase of the number of victims and property losses by evacuating them to places considered safe for them. Furthermore, as the conditions were still heated and peace efforts could not be achieved in a short time, the Government decided to provide shelters in other areas to prevent direct contact between these two communities. To the displaced community, the Shia, the Government also provided with the refugee status.

Soon after the conflict, the Government carried-out several meetings between the two parties to achieve peace through mediation and/or reconciliation process. The Shia, in this case, was represented by one of the National NGOs based in Surabaya, namely KontraS (The Commission for Disappeared and Victims of Violence). To help the refugees, the Government of East Java Province also allocates funds for the cost of living of the refugees every month and budget is purely allocated from the Provincial Government budget. Actually, according to the Government, the obligation to provide with living expenses for the refugees is quite burdensome for the Provincial Government, because there are 82 families with a total of 335 people who are continuously provided with living expenses and facilities during the evacuation. Nevertheless, the Government is committed to continuing providing this facility as long as the Shia community is still living in refugee camps. According to the government, the decision to continue providing the cost of living, in addition to human rights considerations, is also to avoid the reaction and harsh criticism from the international community. In addition to the cost of living, during the evacuation, the children of the Shia community are also given facilities to attend school and all refugees are also provided with health inspection facilities. These facilities have been provided for more than 5 (five) years. Although the peace process has been seriously mediated by the Government and has been going on for so long, until recently, the situation has not changed.

In the name of Human Rights, the Shia community wants to return to their hometown, but the Sunni community in Sampang refuses them. If the Shia community is about to return to Sampang, there are severe conditions imposed upon them that they must make a 'social conversion' and declare themselves to be back to the religious teachings held by the Sunni. For the Shia community, such coercion is considered a violation of the human right because they have the right to believe and worship in accordance with their beliefs as guaranteed by the constitution. The relocation option has also been offered by the Government, but this option is rejected on the grounds that it will become a bad precedent in the future. Even if the Shia community finally insists on returning to their hometown, there is another dilemma about their safety that will be the burden of the state. Under these conditions, the whole process of peace and reconciliation is actually deadlocked.

\section{Lack of Arrangements in National and Regional Legislation on When to End State Responsibility in Conflict Handling}

Based on Law no. 7 of 2012 and its implementation rule, i.e. the Government Regulation no. 2 of 2015, the establishment of a state of conflict is defined if the conflict escalation encompasses and affects a particular region. The area covers the district/city and/or provincial or national levels. Those determining that status at the district/municipality level are the Regents/Mayors after consultation with the head of district/city House of 
Representatives. At the provincial level, the status is determined by the Governor after consultation with the head of the provincial House of Representatives and at the national level established by the President after consultation with the head of the House of Representatives.

How soon will the state of the conflict be defined? Article 22 of Law no. 7 of 2012 stipulates that the determination of the state of the conflict shall remain in force for a maximum of 90 (ninety) days. It further stipulates that based on the evaluation of the conflict at the district/municipality, provincial or national level, after consultation with the head of the House of Representatives, either the Regent/ Mayor or the Governor or the President can only extend the period of conflict status by 30 days. Based on these rules, the law only establishes a state of conflict for a total of 120 days or approximately 4 (four) months.

What then should the state do if the conflict and peace efforts cannot be resolved? This question is important considering there are various consequences of the non-completion of this process. One of the consequences is whether the status of the conflict situation is still ongoing. If a conflict is not resolved like the one in Sampang, can the time then be extended? Another consequence of this situation is the cost of handling the conflict that becomes the responsibility of the State c.q. The Government. As regulated, funding or budget for handling the conflict shall be the responsibility of the Government and the Regional/Local Government in accordance with its authority, whereby the source of funding for conflict handling may come from the State Budget (APBN), and the local budget(APBD), and/or from the society. Does the state,c.q. The Government still have to bear the cost of living of all refugees continuously? Both of these are not regulated in both legislations. Having attempted to resolve the conflict, but the conflicting parties are unwilling to accept the options given, will this burden still become the responsibility of the state? What if the peace process cannot be achieved forever? Will the state also have to bear this responsibility forever?

\section{Acknowledgements}

This paper is part of PUPT research funded by the Ministry of Research, Technology and Higher Education of the Republic of Indonesia with the DIPA budget of 2017. Our gratitude goes to all research subjects, i.e. the Government of East Java Province and Sampang District, friends from the Sunni and Shia community, and friends from KontraS Surabaya.

\section{References}

[1] Amal, Ichlasul in Soeharto, BambangW.,"Menangani Konflik di Indonesia”, Jakarta: KataHastaPusaka, 2013, p.xv

[2] Simandjuntak, Marcella Elwina, 2015, Intercultural Dialog and Education: Promoting Social Conflict Reconciliation and Peace Building Initiative Methods into Law School Curricula, in $23^{\text {rd }}$ ASEACCU Anual Conference and Student Camp, Semarang, August 25-29, 2015, p.111. See also Hadar, Ivan, Berbeda tanpa Konflik, in Paul Tahalele (ed.), Indonesia di Persimpangan Kekuasaan: Dominasi Kekerasan Publik atas Dialog Publik, 2000, Jakarta: theGo-East Institute, p.22

[3] Nugroho, Kris dan Santoso, Thomas, “Episode Tahun Kekerasan 1996-1999”, in Paul Tahalele et.al., 2000, Indonesia di Persimpangan Kekuasaan: Dominasi Kekerasan Publik atas Dialog Publik, Jakarta: the Go-East Institute, 2000, p.66

[4] Sacks, Jonathan, "Not in God's Name: Confronting Religious Violence”, London: Hodder \& Stoughton Ltd., 2015, p. 3

[5] Bojana Blagojevic, "Causes of Ethnic Conflict: A Conceptual Framework", Journal of Global Change and Governance, Volume III, Number 1, Winter 2009, New York: Rutgers Univ., pp.2-3

[6] Haidt, Jonathan, "The Righteous Mind: Why Good People are Devided by Politics and Religion”, New York: Vintage, 2012, pp. 219-221 